\title{
Fervidobacterium changbaicum sp. nov., a novel thermophilic anaerobic bacterium isolated from a hot spring of the Changbai Mountains, China
}

\author{
Correspondence \\ Yan Feng \\ yfeng@mail.ju.edu.cn \\ Yanhe Ma \\ mayanhe@im.ac.cn
}

\author{
Jingang Cai, ${ }^{1}$ Yanping Wang, ${ }^{1}$ Dongbo Liu, ${ }^{2}$ Yan Zeng, ${ }^{3}$ Yanfen Xue, ${ }^{3}$ \\ Yanhe $\mathrm{Ma}^{3}$ and Yan Feng ${ }^{1}$ PR China
${ }^{2}$ School of Life Science, Northeast Normal University, Changchun 130024, PR China
${ }^{3}$ State Key Laboratory of Microbial Resources, Institute of Microbiology, Chinese Academy of Sciences, Beijing 100080, PR China \\ ${ }^{1}$ Key Laboratory for Molecular Enzymology and Engineering, Jilin University, Changchun 130023
}

\begin{abstract}
A thermophilic, obligately anaerobic, rod-shaped bacterium (strain CBS $-1^{\top}$ ) was isolated from a hot spring mixture of water and mud of the Changbai Mountains, China. Strain CBS $-1^{\top}$ was found to be non-sporulating, Gram-negative, with optimal growth at $75-80{ }^{\circ} \mathrm{C}$. It grew on a wide range of carbon sources, including glucose, lactose, maltose, starch, sorbitol and pyruvate amongst others. The DNA G $+C$ content of strain CBS- $1^{\top}$ was 31.9 mol\%. The $16 \mathrm{~S}$ rRNA gene sequence analysis indicated that the strain was a member of the genus Fervidobacterium. The high concentration of $\mathrm{C}_{16: 0}(52.2 \%)$ in the fatty acid profile of the cell envelope supported its inclusion as a member of the genus Fervidobacterium. On the basis of the low values of DNA-DNA hybridization (25.8 and $20.5 \%$ ) and phenotypic features, strain CBS $-1^{\top}$ represents a novel species of the genus Fervidobacterium, for which the name Fervidobacterium changbaicum sp. nov. is proposed. The type strain is CBS-1 ${ }^{\top}\left(=\mathrm{DSM} 17883^{\top}=\mathrm{JCM} 13353^{\top}\right)$.
\end{abstract}

Based on the morphological, physiological and biochemical characteristics, the genus Fervidobacterium was proposed in 1985 (Patel et al., 1985). Currently, the genus comprises four species with validly published names: Fervidobacterium nodosum (Patel et al., 1985), Fervidobacterium islandicum (Huber et al., 1990), Fervidobacterium gondwanense (Andrews \& Patel, 1996) and Fervidobacterium pennivorans (Friedrich \& Antranikian, 1996). All species of the genus Fervidobacterium have been isolated from geothermal waters. The Changbai Mountains $\left(42^{\circ} \mathrm{N}, 128^{\circ} 1^{\prime} \mathrm{E}\right.$; $2189 \mathrm{~m}$ altitude) of China is a resting volcano, and possesses many hot springs with temperatures ranging from 60 to $83{ }^{\circ} \mathrm{C}$. The high temperature, sulphur-enriched and remote geographical location makes these hot springs a new habitat for searching for thermophiles. To date, no thermophilic microorganism from these hot springs has been reported. In this study, we describe a novel thermophilic anaerobic bacterium isolated from a hot spring of the Changbai

The GenBank/EMBL/DDBJ accession number for the $16 \mathrm{~S}$ rRNA gene sequence of strain CBS-1 ${ }^{\top}$ is AY878719.

An electron micrograph of cells of strain $\mathrm{CBS}-1^{\top}$, graphs showing the influence of temperature, $\mathrm{pH}$ and salt concentration on growth of cells of strain CBS $-1^{\top}$ and fatty acid compositions of strain CBS $-1^{\top}$ are available as supplementary material with the online version of this paper.
Mountains, and propose a novel species, Fervidobacterium changbaicum sp. nov.

A sample mixture of water and mud (approx. $400 \mathrm{ml}$ ) was collected from the edge of a hot spring of the Changbai Mountains, China. The $\mathrm{pH}$ of the water was 7.2. The enrichment and isolation procedures were performed anaerobically at $80{ }^{\circ} \mathrm{C}$ in TYE medium with sulphur $(1 \%, w / v)$ and $\mathrm{Na}_{2} \mathrm{~S} .9 \mathrm{H}_{2} \mathrm{O}(0.05 \%$, w/v $)$. TYE medium contained $\left(\mathrm{l}^{-1}\right)$ : $\left(\mathrm{NH}_{4}\right)_{2} \mathrm{SO}_{4}(1.3 \mathrm{~g}), \mathrm{KH}_{2} \mathrm{PO}_{4}(0.28 \mathrm{~g})$, $\mathrm{MgSO}_{4} \cdot 7 \mathrm{H}_{2} \mathrm{O}(0.25 \mathrm{~g}), \mathrm{CaCl}_{2}(0.07 \mathrm{~g}), \quad \mathrm{FeSO}_{4} \cdot 7 \mathrm{H}_{2} \mathrm{O}$ $(0.028 \mathrm{~g}), \quad \mathrm{MnCl}_{2} \quad(1.8 \mathrm{mg}), \quad \mathrm{Na}_{2} \mathrm{~B}_{4} \mathrm{O}_{7} \quad$ (4.5 mg), $\mathrm{ZnSO}_{4} \cdot 7 \mathrm{H}_{2} \mathrm{O} \quad(0.22 \mathrm{mg}), \quad \mathrm{CuSO}_{4} \cdot 2 \mathrm{H}_{2} \mathrm{O} \quad(0.05 \mathrm{mg})$, $\mathrm{NaMoO}_{4} \cdot 2 \mathrm{H}_{2} \mathrm{O}(0.03 \mathrm{mg}), \mathrm{CoCl}_{2}(0.01 \mathrm{mg})$, yeast extract $(1 \mathrm{~g})$, tryptone $(2 \mathrm{~g})$ and $0.1 \%(\mathrm{v} / \mathrm{v})$ resazurin. The medium was adjusted to $\mathrm{pH} 7.0$ with $1 \mathrm{M} \mathrm{NaOH}$. Positive cultures were transferred to the same fresh medium at least three times. Purification was done using the end-point dilution method (Patel et al., 1985) and Hungate roll tubes with TYE agar [3\% (w/v) of agar] at $65{ }^{\circ} \mathrm{C}$. A single colony was picked and cultivated. The purified strain was designated CBS $-1^{\mathrm{T}}$.

F. islandicum DSM $5733^{\mathrm{T}}$ and F. pennivorans DSM $9078^{\mathrm{T}}$ purchased from DSMZ (Deutsche Sammlung von Mikroorganismen und Zellkulturen, Braunschweig, Germany) were used as the reference strains for determination of 
DNA G $+\mathrm{C}$ content and DNA hybridization, and anaerobically incubated at $65{ }^{\circ} \mathrm{C}$ (Huber et al., 1990). The physiological tests were performed according to Bergey's manual (Buchanan et al., 1974). Unless otherwise indicated, all physiological experiments were performed in triplicate. The optimal conditions for growth were determined in TYE medium. To determine the $\mathrm{pH}$ range for growth, TYE medium was adjusted from $\mathrm{pH} 4.0$ to 10.0 by injecting different volumes (with $50 \mu \mathrm{l}$ steps) of sterile $1 \mathrm{M} \mathrm{HCl}$ or $1 \mathrm{M} \mathrm{NaOH}$. Cell morphology was examined by light microscopy Hitachi S-570. Substrate utilization was determined in the modified TYE medium without yeast extract, and the final concentration of substrates was $0.5 \%(\mathrm{w} / \mathrm{v})$. Antibiotics were added from filter-sterilized stock solutions to sterile TYE medium under anaerobic conditions to give a final concentration of 10 and $100 \mu \mathrm{g} \mathrm{ml}^{-1}$.

Cellular fatty acid profile was studied as described previously (Nazina et al., 2001). Genomic DNA was prepared by using the method of Marmur (1961) and the purity was checked spectrometrically. The $\mathrm{G}+\mathrm{C}$ content of genomic DNA was determined by thermal denaturation $\left(T_{\mathrm{m}}\right)$ (Marmur \& Doty, 1962). The $16 \mathrm{~S}$ rRNA gene was amplified using 27f (5'-AGAGTTTGATCCTGGCTCAG$\left.3^{\prime}\right)$ (Sakai et al., 2003) and 1541r (5'-AAGGAGGTGATCCAGCCGCA-3') primers (Peña et al., 2004). The almost-complete $16 \mathrm{~S}$ rRNA gene sequence of strain CBS- $1^{\mathrm{T}}$ was determined and aligned with other 16S rRNA gene sequences of closely related strains, available in the GenBank database, using CLUSTAL W version 1.8 (Thompson et al., 1994). The phylogenetic tree was constructed from a distance matrix based on the neighbour-joining method (Saitou \& Nei, 1987) in the TREECON program (Van de Peer \& De Wachter, 1995) (Fig. 1). DNA-DNA hybridization was performed by the thermal denaturation and renaturation method (De Ley et al., 1970). Temperature of optimum renaturation was defined as the temperature $25{ }^{\circ} \mathrm{C}$ lower than the $T_{\mathrm{m}}$ value. The highest and lowest values obtained in each sample were excluded and the remaining three values were used to calculate similarity values. The DNA relatedness values quoted are the mean of the three values.
Cells of strain CBS- $1^{\mathrm{T}}$ stained Gram-negative, rod-shaped. Cell sizes were approximately $0.5-0.6 \times 1.0-8.0 \mu \mathrm{m}$ after $48 \mathrm{~h}$ anaerobic cultivation at $80{ }^{\circ} \mathrm{C}$ on TYE medium (Supplementary Fig. S1 available in IJSEM Online). All of the colonies appeared smooth, ivory-white round and were about $1 \mathrm{~mm}$ in diameter after 4 days of anaerobic cultivation at $65^{\circ} \mathrm{C}$ on TYE agar medium. In TYE medium, no spore formation was observed at any temperature or $\mathrm{pH}$ values. Spheroid structure, the protuberances of the outer cell wall that consisted in the strains of the genus Fervidobacterium, was also observed in strain CBS- $1^{\mathrm{T}}$ after $24 \mathrm{~h}$ incubation at $75{ }^{\circ} \mathrm{C}$ (data not shown). In the presence of sulphur powder, the growth of strain $\mathrm{CBS}-1^{\mathrm{T}}$ was stimulated and $\mathrm{H}_{2} \mathrm{~S}$ was generated, which is similar to other members of the genus Fervidobacterium. The substrates that supported the growth of strain CBS- $1^{\mathrm{T}}$ included glucose, lactose, D-fructose, sucrose, maltose, starch, sorbitol, cellobiose, trehalose dihydrate, D-galactose, meso-erythritol, dulcitol, chrysanthanol, melibiose, pyruvate, dextrin and glycerin, but D-raffinose, D-glucuronic acid, agarose, L-rhamnose, D-gluconic acid lactone, sodium malate, mannose, mannitol, L-arabinose and ribose do not support growth. Growth of strain CBS- $1^{\mathrm{T}}$ was completely inhibited by streptomycin, chloramphenicol, carbenicillin, kanamycin, ampicillin and tetracycline $\left(10 \mu \mathrm{g} \mathrm{ml}^{-1}\right)$, and $100 \mu \mathrm{g}$ neomycin $\mathrm{ml}^{-1}$.

The $\mathrm{G}+\mathrm{C}$ content of genomic DNA of strain CBS- $1^{\mathrm{T}}$ was $31.9 \pm 0.3 \mathrm{~mol} \%\left(T_{\mathrm{m}}\right)$, and that of $F$. islandicum DSM $5733^{\mathrm{T}}$ was determined as $41.3 \mathrm{~mol} \%$ in our study when used as a control; however, a value of $40.0 \mathrm{~mol} \%$ was reported previously (Huber et al., 1990). The fatty acid profile of strain CBS- $1^{\mathrm{T}}$ was mainly composed of $\mathrm{C}_{16: 0}$ (52.2\%), iso- $\mathrm{C}_{14: 0}(11.7 \%), \mathrm{C}_{18: 0}(6.4 \%)$ and $\mathrm{C}_{18: 1} \omega 9 \mathrm{c}$ $(4.5 \%)$ (Supplementary Table S1 available in IJSEM Online). For the composition of fatty acids, $\mathrm{C}_{16: 0}$ $(52.2 \%)$ was the dominant fatty acid similar to Fervidobacterium species (46.7-81.8\%, Patel et al., 1991; Huber et al., 1990). However, there was considerable variation in the saturated and branched saturated fatty acid composition in Fervidobacterium species as described previously. The saturated fatty acid content of F. nodosum

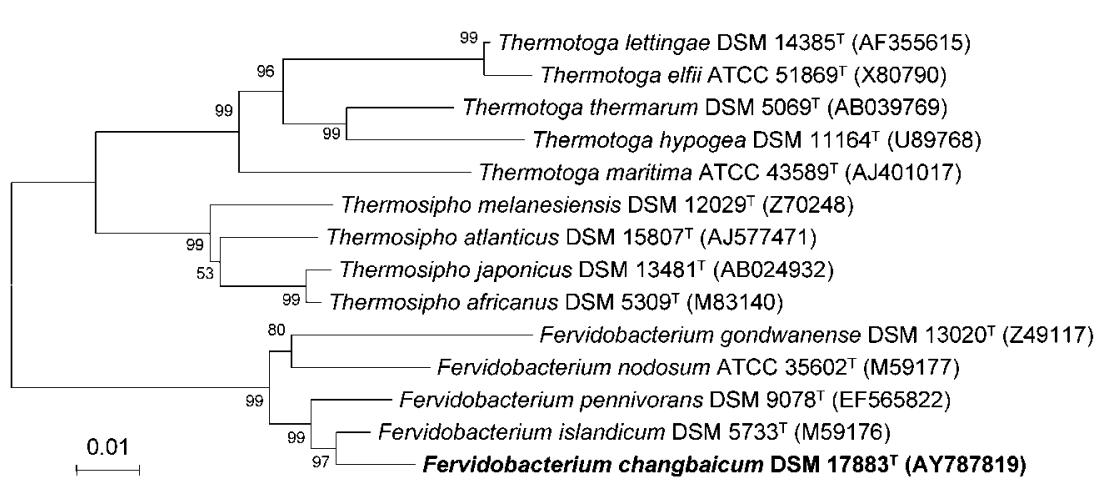

Fig. 1. Phylogenetic tree based on $16 \mathrm{~S}$ rRNA gene sequence showing the relationship of strain CBS $-1^{\top}$ to members of the family Thermotogaceae. The dendrogram was constructed by using the neighbour-joining method. Jukes-Cantor evolutionary distance matrix data was obtained from a comparison of 1300 unambiguous nucleotides as implemented in PHYLIP (Felsenstein, 1988). The sequences used in the analysis were obtained from the GenBank database. Bar, 1 substitution at any nucleotide position per 100 nucleotide positions. 
ATCC $35602^{\mathrm{T}}(87.1 \%)$ and F. islandicum DSM $5733^{\mathrm{T}}$ $(86.7 \%)$ was higher than that of $F$. gondwanense DSM $13020^{\mathrm{T}}(78.5 \%)$ and strain CBS- $1^{\mathrm{T}}(61.1 \%)$. Branched saturated fatty acid content of strain CBS- $1^{\mathrm{T}}$ was $24.8 \%$, obviously different from Fervidobacterium species (not detected in F. nodosum ATCC $35602^{\mathrm{T}}$ ). The $16 \mathrm{~S}$ rRNA gene sequence similarity between strain $\mathrm{CBS}-1^{\mathrm{T}}$ and Fervidobacterium species was $93.0-97.5 \%$. Strain CBS- $1^{\mathrm{T}}$ was closer to $F$. pennivorans DSM $9078^{\mathrm{T}}$ and $F$. islandicum DSM $5733^{\mathrm{T}}$ (97.5 and $97.2 \%$ sequence similarity, respectively). However, the DNA-DNA hybridization result also exhibited a very low level of similarity (25.8 and $20.5 \%$ hybridization values, respectively) between strain CBS- $1^{\mathrm{T}}$ and the two relative species. This data suggests that strain CBS $-1^{\mathrm{T}}$ is not related at species level to $F$. pennivorans and $F$. islandicum. In addition, strain CBS- $1^{\mathrm{T}}$ showed significant physiological characteristic differences from Fervidobacterium species, including temperature and salinity for growth amongst others (Table 1). The growth temperature of strain CBS- $1^{\mathrm{T}}$ ranged from 55 to $90{ }^{\circ} \mathrm{C}$, with the optimum growth temperature at $75-80{ }^{\circ} \mathrm{C}$ (Supplementary Fig. S2 available in IJSEM Online), while other species could barely grow at $80{ }^{\circ} \mathrm{C}$, indicating that strain CBS $-1^{\mathrm{T}}$ was more thermophilic than the other four Fervidobacterium species. Furthermore, the genomic DNA of strain $\mathrm{CBS}-\mathrm{1}^{\mathrm{T}}$ exhibits the lowest $\mathrm{G}+\mathrm{C}$ content of the genus Fervidobacterium.
Overall, our data indicate that strain CBS- $1^{\mathrm{T}}$ represents a novel species of the genus Fervidobacterium, for which the name Fervidobacterium changbaicum sp. nov. is proposed.

\section{Description of Fervidobacterium changbaicum sp. nov.}

Fervidobacterium changbaicum (chang.bai'cum. N.L. neut. adj. changbaicum, pertaining to the isolation of the organism from the Changbai Mountains, China).

Rod-shaped, non-sporulating, Gram-negative bacterium. Growth occurs at $55-90{ }^{\circ} \mathrm{C}$ (optimum $75-80{ }^{\circ} \mathrm{C}$ ), at $\mathrm{pH}$ 6.3-8.5 (optimum 7.5), at $\mathrm{NaCl}$ concentration less than $10.0 \mathrm{~g} \mathrm{l}^{-1}$ and at $\mathrm{MgCl}_{2}$ concentration less than $3.0 \mathrm{~g} \mathrm{l}^{-1}$ (optimum $0.5 \mathrm{~g} \mathrm{l}^{-1}$ ). Cell size is $0.5-0.6 \times 1.0$ $8.0 \mu \mathrm{m}$. Can utilize glucose, lactose, D-fructose, sucrose, maltose, starch, sorbitol, cellobiose, trehalose dihydrate, Dgalactose, meso-erythritol, dulcitol, chrysanthanol, melibiose, pyruvate, dextrin and glycerin, but not D-raffinose, D-glucuronic acid, agarose, L-rhamnose, D-gluconic acid lactone, sodium malate, mannose, mannitol, L-arabinose or ribose. Sulphur powder can stimulate growth. Growth is inhibited by streptomycin, chloramphenicol, carbenicillin, kanamycin, ampicillin and tetracycline $\left(10 \mu \mathrm{g} \mathrm{ml}^{-1}\right)$, and $100 \mu \mathrm{g}$ neomycin $\mathrm{ml}^{-1}$. The fatty acid profile is mainly composed of $\mathrm{C}_{16: 0}(52.2 \%)$, iso- $\mathrm{C}_{14: 0}(11.7 \%), \mathrm{C}_{18: 0}$

Table 1. Differential characteristics of members of the genus Fervidobacterium

Taxa: 1, F. gondwanense DSM $13020^{\mathrm{T}}$ (Andrews \& Patel, 1996); 2, F. nodosum ATCC $35602^{\mathrm{T}}$ (Patel et al., 1985); 3, F. islandicum DSM 5733 ${ }^{\mathrm{T}}$ (Huber et al., 1990); 4, F. pennivorans DSM $9078^{\mathrm{T}}$ (Friedrich \& Antranikian, 1996); 5, F. changbaicum CBS- ${ }^{\mathrm{T}}$ (this study). +, Positive; -, negative; NR, not reported. All strains utilized glucose, starch and maltose.

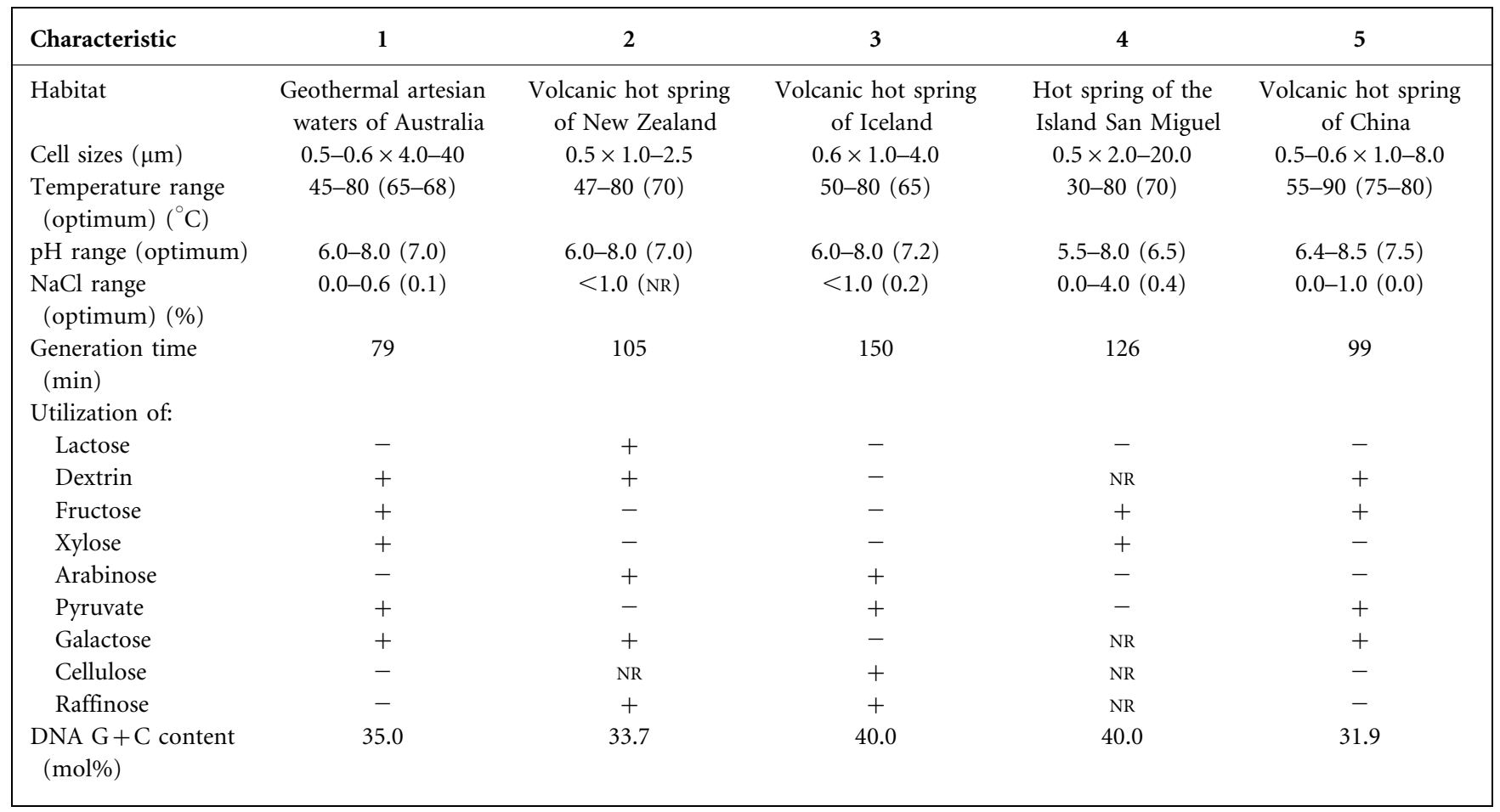


$(6.4 \%)$ and $\mathrm{C}_{18: 1} \omega 9 c(4.5 \%)$. The $\mathrm{G}+\mathrm{C}$ content of genomic DNA is $31.9 \pm 0.3 \mathrm{~mol} \%\left(T_{\mathrm{m}}\right)$.

The type strain, CBS- $1^{\mathrm{T}}\left(=\mathrm{DSM} 17883^{\mathrm{T}}=\mathrm{JCM} 13353^{\mathrm{T}}\right)$, was isolated from a hot spring mixture of water and mud of the Changbai Mountains, China.

\section{Acknowledgements}

This work was supported by grants from the 973 programs (2004CB719600 and 2003CB716000), and 863 program (2004AA214060).

\section{References}

Andrews, K. T. \& Patel, B. K. C. (1996). Fervidobacterium gondwanense sp. nov., a new thermophilic anaerobic bacterium isolated from nonvolcanically artesian basin of Australia. Int J Syst Bacteriol 46, 265-269.

Buchanan, R. E., Gibbons, N. E., Cowan, S. T., Holt, J. G., Liston, J., Murray, R. G. E., Niven, C. F., Ravin, A. W. \& Stanier, R. Y. (1974). Bergey's Manual of Determinative Bacteriology, 8th edn. Baltimore: Williams \& Wilkins.

De Ley, J., Cattoir, H. \& Reynaerts, A. (1970). The quantitative measurement of DNA hybridization from renaturation rates. Eur $J$ Biochem 12, 133-142.

Felsenstein, J. (1988). Phylogenies from molecular sequences: inference and reliability. Annu Rev Genet 22, 521-565.

Friedrich, A. B. \& Antranikian, G. (1996). Keratin degradation by Fervidobacterium pennavorans, a novel thermophilic anaerobic species of the order Thermotogales. Appl Environ Microbiol 62, 2875-2882.

Huber, R., Woese, C. R., Langworthy, T. A., Kristjansson, J. K. \& Stetter, K. O. (1990). Fervidobacterium islandicum sp. nov., a new extremely thermophilic eubacterium belonging to the "Thermotogales". Arch Microbiol 154, 105-111.

Marmur, J. (1961). A procedure for the isolation of deoxyribonucleic acid from microorganisms. J Mol Biol 3, 208-218.
Marmur, J. \& Doty, P. (1962). Determination of the base composition of deoxyribonucleic acid from its thermal denaturation temperature. $J$ Mol Biol 5, 109-118.

Nazina, T. N., Tourova, T. P., Poltaraus, A. B., Novikova, E. V., Grigoryan, A. A., Ivanova, A. E., Lysenko, A. M., Petrunyaka, V. V., Osipov, G. A. \& other authors (2001). Taxonomic study of aerobic thermophilic bacilli: descriptions of Geobacillus subterraneus gen. nov., sp. nov. and Geobacillus uzenensis sp. nov. from petroleum reservoirs and transfer of Bacillus stearothermophilus, Bacillus thermocatenulatus, Bacillus thermoleovorans, Bacillus kaustophilus, Bacillus thermoglucosidasius and Bacillus thermodenitrificans to Geobacillus as the new combinations G. stearothermophilus, G. thermocatenulatus, G. thermoleovorans, G. kaustophilus, G. thermoglucosidasius and G. thermodenitrificans. Int J Syst Evol Microbiol 51, 433-446.

Patel, B. K. C., Morgan, H. W. \& Daniel, R. M. (1985). Fervidobacterium nodosum gen. nov. and spec. nov., a new chemoorganotrophic, caldoactive, anaerobic bacterium. Arch Microbiol 141, 63-69.

Patel, B. K. C., Skerratt, J. H. \& Nichols, P. D. (1991). The phospholipid ester-linked fatty acid composition of thermophilic bacteria. Syst Appl Microbiol 14, 311-316.

Peña, J. A., Li, S. Y., Wilson, P. H., Thibodeau, S. A., Szary, A. J. \& Versalovic, J. (2004). Genotypic and phenotypic studies of murine intestinal lactobacilli: species differences in mice with and without colitis. Appl Environ Microbiol 70, 558-568.

Saitou, N. \& Nei, M. (1987). The neighbor-joining method: a new method for reconstructing phylogenetic trees. Mol Biol Evol 4, 406-425.

Sakai, T., Ishizuka, K. \& Kato, I. (2003). Isolation and characterization of a fucoidan-degrading marine bacterium. Mar Biotechnol 5, 409-416.

Thompson, J. D., Higgins, D. G. \& Gibson, T. J. (1994). CLUSTAL W: improving the sensitivity of progressive multiple sequence alignment through sequence weighting, position-specific gap penalties and weight matrix choice. Nucleic Acids Res 22, 4673-4680.

Van de Peer, Y. \& De Wachter, R. (1995). TREECON for Windows: a software package for the construction and drawing of evolutionary trees for the Microsoft Windows environment. Comput Appl Biosci 10, 569-570. 